\title{
Enantioselective Hydrogenation of Ethyl Pyruvate and 1-Phenyl-1,2-propanedione on Catalysts Prepared by Impregnation of Colloidal Platinum on $\mathrm{SiO}_{2}$
}

\author{
Doris P. Ruiz, ${ }^{a}$ José L. G. Fierro ${ }^{b}$ and Patricio A. Reyes*,a \\ ${ }^{a}$ Departamento de Fisicoquímica, Facultad de Ciencias, Universidad de Concepción, \\ Casilla 160-C Concepción, Chile
}

${ }^{b}$ Instituto de Catálisis y Petroleoquímica, CSIC, Marie Curie 2, Cantoblanco 28049 Madrid, Spain

\begin{abstract}
A hidrogenação enantiosseletiva de piruvato de etila e de 1-fenil-1,2-propanodiona foi estudada a $298 \mathrm{~K}$ e sob 40 bar de $\mathrm{H}_{2}$ sobre um catalisador de platina coloidal estabilizado com cinchonidina (CD) e suportado em sílica. O catalisador foi preparado por impregnação da platina coloidal em sílica, atingindo $1 \%$ em massa do metal no suporte. O colóide foi preparado a partir de uma solução aquosa de $\mathrm{H}_{2} \mathrm{PtCl}_{6}$ estabilizada com diferentes quantidades de $\mathrm{CD}$. O catalisador foi caracterizado por isotermas de adsorção-desorção de $\mathrm{N}_{2}$ a 77 K e por XPS, XRD e TEM. As reações foram efetuadas em batelada em um reator de aço inoxidável, usando cicloexano como solvente e cinchonidina como modificador quiral. A adição de CD ao catalisador permite a estabilização e o controle do tamanho de partícula da platina, e também afeta o excesso enantiomérico (ee) do sistema, levando a um maior rendimento do produto com configuração $R$. A relação entre a concentração de CD adicionada in situ e a enantiosseletividade apresenta uma curva do tipo sino nas duas reações estudadas; este comportamento é um indicativo da importância da adsorção competitiva do modificador e do substrato na superfície do catalisador.
\end{abstract}

The enantioselective hydrogenation of ethyl pyruvate and 1-phenyl-1,2-propanedione was studied at $298 \mathrm{~K}$ and 40 bar of $\mathrm{H}_{2}$ over colloidal Pt stabilized with cinchonidine (CD) and supported on silica. The catalysts were prepared by impregnation of colloidal $\mathrm{Pt}$ on $\mathrm{SiO}_{2}$, leading to a metal load close to $1 \mathrm{wt}$. \% . The colloid was prepared from an aqueous solution of $\mathrm{H}_{2} \mathrm{PtCl}_{6}$ and stabilized with different quantities of $\mathrm{CD}$. The catalysts were characterized by nitrogen adsorption-desorption isotherms at $77 \mathrm{~K}$, XPS, XRD and TEM techniques. The reactions were carried out in a stainless steel batch reactor using cyclohexane as solvent and cinchonidine as chiral modifier. The addition of $\mathrm{CD}$ to the catalysts allows the stabilization and control of the platinum particle size and also affects the enantiomeric excess $(e e)$ of the system, affording a higher proportion of the $(R)$-product. The relationship between the enantioselectivity and the CD concentration (added in situ) exhibits a bell type curve for both reactions, this being indicative of the importance of a competitive adsorption of the modifier and substrate on the catalyst surface.

Keywords: Pt colloids, enantioselectivity, ethyl pyruvate, 1-phenyl-1,2-propanedione, cinchonidine

\section{Introduction}

Enantioselective hydrogenation reactions are important tools to obtain fine chemicals used in pharmaceutical and food products. ${ }^{1-4}$ Thus, the synthesis of chiral compounds is of growing interest; among them, the hydrogenation of $\alpha$-ketoesters and ketones is the most widely studied. ${ }^{5-15}$ Since Orito et al. reported the enantioselective hydrogenation of ethyl pyruvate to $(R)$-ethyl lactate over cinchonidine-modified Pt catalysts

*e-mail: preyes@udec.cl with $e e$ 's up to $95 \%$, many other research teams have evaluated the performance of their catalytic systems in this reaction. ${ }^{16-18}$ Indeed, this is nowadays a sort of test reaction in the field of asymmetric catalysis. However, when the substrate has more than one centre to be hydrogenated the reaction becomes more difficult, as occurs during the hydrogenation of diones (such as 1-phenyl-1,2-propanedione), both in terms of enantioand regioselectivity $(R S) .{ }^{19-26}$ In this case, the product of interest is $(R)$-1-phenyl-1-hydroxy-2-propanone, which has interesting applications in the synthesis of precursors for hypertension and asthma treatments, among others. ${ }^{27-28}$ 
Supported platinum catalysts have been widely studied for this type of application. ${ }^{29}$ It has been found that metal particle size plays an important role in asymmetric synthesis when performed in the presence of cinchonidine as a chiral inducer. Metal crystals around $3.0 \mathrm{~nm}$ obtained with catalysts having metal loading close to $5 \mathrm{wt}$.\% have led to the most promising catalytic behaviour. The catalysts containing lower metal loadings usually display smaller particle sizes and are not appropriate for this purpose. However, using colloid preparation procedures, it is possible to obtain metal particles with different average sizes. In this case, even with low metal loading it is possible to get larger metal crystals. In fact, it is well known that metal colloids with different particle sizes can be prepared by this procedure in the presence of a chiral inducer, which may lead to preferential hydrogenation to $(R)$-ethyl lactate during hydrogenation of ethyl pyruvate. ${ }^{30-38}$

On the other hand, it is also well known that, in different reaction conditions, there may be leaching from nanoparticles..$^{39-41}$ The leaching mainly occurs in reactions at high temperatures or carried out under extreme conditions, such as C-C coupling, Heck reaction, etc.. Taking into account this important phenomenon, we tried to reduce the leaching problems from our catalysts to a minimum level. ${ }^{42}$ We have employed conditions that decrease this effect, such as the use of nanoparticles on a support that can stabilize the metal clusters or inhibit the release of metal atoms from the particles. Also, in the hydrogenation reactions the solvent used was of low polarity and non oxidant, this to avoid the solvolysis of the metal-oxygen bonds through which the catalyst is attached to the $\mathrm{SiO}_{2}$.

In this work, supported Pt catalysts were synthesized in which the active phase was first obtained from a colloidal dispersion and then impregnated on the support. Cinchonidine (CD), which is often used as a chiral inducer, was employed as colloid stabilizer because it limits the excessive growth of metal particles. Additionally, CD may induce enantioselectivity towards the desired product. As it is well known, most of the heterogeneous asymmetric hydrogenations are performed at room temperature with addition of the chiral inducer and the substrate at the beginning of the reaction, being this temperature the most appropriate to obtain $\mathrm{CD}$ in its open 3 conformation. ${ }^{38}$ However, at higher temperatures, this inducer exists, in a certain extent, in other conformations. Consequently, in some experiments an additional amount of $\mathrm{CD}$ was also provided with the substrate, and considering that in the colloidal synthesis the extent of $\mathrm{CD}$ added may not be the appropriate. The modified colloidal platinum was supported on commercial silica and the catalytic activity was studied in two reactions: the hydrogenation of ethyl pyruvate and the hydrogenation of 1-phenyl-1,2-propanedione. Both reactions were performed at $298 \mathrm{~K}$ and 40 bar of $\mathrm{H}_{2}$ using cyclohexane as solvent in a batch reactor. The catalysts were characterized by powder XRD (X-ray diffractometry), TEM (transmission electron microscopy) and XPS (X-ray photoelectron spectroscopy).

\section{Experimental}

\section{Materials}

Chloroplatinic acid hydrate, 1-phenyl-1,2-propanedione, ethyl pyruvate, cinchonidine and cyclohexane were supplied by Aldrich, formic acid by Merck and $\mathrm{H}_{2}$ (99.995\%) by AGA. The substrates and solvents were purified by distillation prior to each hydrogenation reaction.

\section{Catalyst preparation}

The colloids were prepared from an aqueous solution of $\mathrm{H}_{2} \mathrm{PtCl}_{6} \cdot 6 \mathrm{H}_{2} \mathrm{O}$ under reflux at $373 \mathrm{~K}$ with the addition of $\mathrm{CD}$ dissolved in $15 \mathrm{~mL}$ of an aqueous $\left(0.1 \mathrm{~mol} \mathrm{~L}^{-1}\right) \mathrm{HCOOH}$ solution. After cooling down to room temperature, the colloid was washed with an aqueous solution of $\mathrm{NaHCO}_{3}$ in order to remove the acidity. The colloidal dispersions were prepared with different quantities of $\mathrm{CD}$, ranging from $2.2 \times 10^{-3}$ to $9.8 \times 10^{-3} \mathrm{~mol} \mathrm{~L}^{-1}$, to give different metal particle sizes. They were labeled as $\mathrm{Pt}-\mathrm{CD}(\mathrm{x}) / \mathrm{SiO}_{2}$ being $\mathrm{x}=2.2$ (a), 7.4 (b) and 9.8 (c) $\mathrm{mmol} \mathrm{L}^{-1}$ of CD respectively. The catalysts were prepared by impregnation of silica (BASF D-11-11, $\mathrm{S}_{\mathrm{BET}}=142 \mathrm{~m}^{2} \mathrm{~g}^{-1}$ ) with an appropriate amount of the colloidal dispersion to get Pt-loadings of $1.0 \mathrm{wt} . \%$. Chemical analysis performed by atomic absorption spectroscopy revealed that the Pt loading was 0.97 wt.\% in the fresh samples, being $0.94 \mathrm{wt} . \%$ in the used catalysts.

\section{Characterization}

Nitrogen adsorption studies were carried out at $77 \mathrm{~K}$ on a Micromeritics ASAP 2010 apparatus. TEM micrographs were obtained with a Jeol Model JEM-1200 EXII System, X-ray diffraction studies were performed with a Rigaku diffractometer and X-ray photoelectron spectra (XPS) were recorded using an Escalab 200R spectrometer provided with a hemispherical analyzer operated in a constant pass energy mode. The $\mathrm{Mg} \mathrm{K}_{\alpha} \mathrm{X}$-ray radiation source $(\mathrm{h} v=1253.6 \mathrm{eV})$ was operated at $10 \mathrm{~mA}$ and $12 \mathrm{kV}$.

\section{Hydrogenation reactions}

The catalytic behaviour in both reactions, the hydrogenation of ethyl pyruvate and 1-phenyl-1,2- 
propanedione, was studied at $298 \mathrm{~K}$ and 40 bar of $\mathrm{H}_{2}$ with cyclohexane as solvent in a stainless steel batch reactor. In reactions that included in situ addition of $\mathrm{CD}$, the amount added at the beginning of the reaction led to an initial concentration of $2 \times 10^{-4} \mathrm{~mol} \mathrm{~L}^{-1}$. The analysis of reactants and products was carried out with a Shimadzu GCMS-QP5050 equipment, using a chiral $\beta$-dex $225,30 \mathrm{~m}$ column (SUPELCO) and helium as carrier gas.

\section{Results and Discussion}

\section{Characterization of catalysts}

X-ray diffraction patterns of the prepared catalysts closely correspond with that displayed by the amorphous silica support. Only a small and wide peak at $2 \theta \mathrm{ca} .40^{\circ}$ corresponding to $\mathrm{Pt}(110)$ was observed in the $\mathrm{Pt}-\mathrm{CD}(\mathrm{a}) /$ $\mathrm{SiO}_{2}$ catalyst. This is a clear indication of the high dispersion of the Pt colloid deposited on the support surface. The absence of diffraction lines due to $\mathrm{Pt}$ in the $\mathrm{X}$-ray diffractograms of the other catalysts ( $\mathrm{b}$ and $\mathrm{c}$ ) can be attributed to the low Pt content and the small particle size, lower than the limit of detection of this technique (usually around $4 \mathrm{~nm}$ ).

Metal particle sizes of both colloidal platinum and Pt$\mathrm{CD} / \mathrm{SiO}_{2}$ catalysts were evaluated by TEM analysis. Particle size measurements showed a very narrow particle size distribution. Table 1 compiles the average values obtained for each colloid, as well as the metal particle size once the impregnation on the support took place. It can be seen that, in both series, the particle size decreases as the $\mathrm{CD}$ concentration used in the synthesis increases. This behaviour can be attributed to the stabilizer role of $\mathrm{CD}$, which inhibits the growth of Pt crystallites formed during the reduction of the precursors. This happens because of the interactions between the partially filled "d" orbitals of the metal and the aromatic ring of the quinoline, the quinuclidinic nitrogen and the oxygen of the stereogenic CD center. Similar results have been reported previously by Bönnemann. ${ }^{31-34}$ Only small changes in the particle size were detected by comparing the colloid dispersion and the corresponding catalysts, confirming the stability of the obtained metal dispersion.

The metal dispersion, estimated from the particle size values assuming a cubic shape for the metallic crystallites, is also given. The results confirm that the used procedure allows an appropriate control of the dispersion or metal particle size. However, if the concentration of $\mathrm{CD}$ is lower than $5 \times 10^{-4} \mathrm{~mol} \mathrm{~L}^{-1}$, the metal particles are much larger and the dispersion becomes unstable.

Microscopy studies included TEM micrographs obtained for fresh and used catalysts, which were analyzed
Table 1. Metal particle sizes determined for the colloidal Pt and Pt-CD(x)/ $\mathrm{SiO}_{2}$ catalysts

\begin{tabular}{lccccc}
\hline Catalyst & $\begin{array}{c}\mathrm{CD} \\
\text { concentration } \\
\left(\mathrm{mol} \mathrm{L}^{-1}\right)\end{array}$ & $\begin{array}{c}\mathrm{Pt} \\
\text { colloidal }\end{array}$ & $\begin{array}{c}1 \mathrm{wt} \% \\
\mathrm{Pt}-\mathrm{CD}(\mathrm{x}) / \\
\mathrm{SiO}_{2}\end{array}$ & Dispersion & $e e^{*}$ \\
\hline (a) & 0.0022 & 3.7 & 3.4 & 0.25 & 23 \\
(b) & 0.0074 & 2.5 & 2.4 & 0.35 & 27 \\
(c) & 0.0098 & 1.7 & 1.6 & 0.53 & 34 \\
\hline
\end{tabular}

Where $\mathrm{x}$ corresponds to (a), (b) and (c). * Enantiomeric excess average for $(R)$-ethyl lactate obtained on $1 \mathrm{wt} . \% \mathrm{Pt}-\mathrm{CD}(\mathrm{x}) / \mathrm{SiO}_{2}$ prepared in the presence of different $\mathrm{CD}$ concentrations.

to verify the possibility of leaching of the supported nanoparticles. We have found no changes in the $\mathrm{Pt}$ nanoparticles size, except in non-supported colloids, in which sinterization of the nanoparticles was detected. Additionally, chemical analysis by atomic absorption spectroscopy did not show significant changes in the $\mathrm{Pt}$ contents of fresh and used catalysts.

Other simple qualitative test performed to analyze the possibility of leaching was to treat the catalyst with THF (a solvent in which the nanoparticles are suspended), followed by filtering of the solid phase. The filtrate was a colorless solution, which roughly indicates that the nanoparticles did not undergo leaching from the support.

The latest research suggests that the only way to verify this phenomenon is the use of special membrane reactors. These membranes have pore diameters smaller than the clusters, and will only allow the passage of atoms (or other chemical species with very small diameters), allowing their separation and quantification. In subsequent works we intend to study some reactions in membrane reactors to verify this behavior at the atomic level.

XPS studies were performed after in situ treatment of the catalysts with hydrogen at room temperature to remove possible surface oxidation. A binding energy of $314.9 \mathrm{eV}$ was found for the $\mathrm{Pt} 4 \mathrm{~d}_{5 / 2}$ core-level, indicating the presence of $\mathrm{Pt}$ in a reduced state $\left(\mathrm{Pt}^{0}\right)$. Indeed, this result can be taken as indicative of the efficiency of the reduction procedure employed in this work, which consists in the decomposition of formic acid in aqueous solution at temperatures close to $80{ }^{\circ} \mathrm{C}$, producing $\mathrm{H}_{2}$ gas to reduce platinum ions to metal particles. Additionally, it should be mentioned that $\mathrm{N} 1 \mathrm{~s}$ core-level spectra showed the presence of two types of nitrogen, centered at $398.0 \pm 0.1$ and $c a .400 \pm 0.1 \mathrm{eV}$, in line with the two different surroundings of nitrogen in the quinolinic and quinuclidinic ring, respectively. As expected, the proportion of both nitrogen atoms is close to 1 in the three catalysts (see Figure 1). 


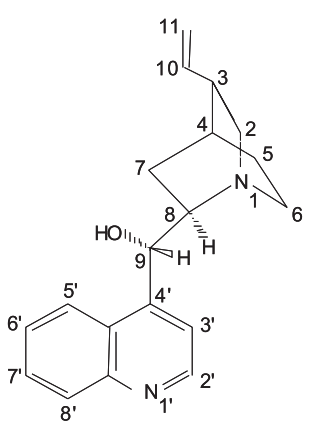

(a)

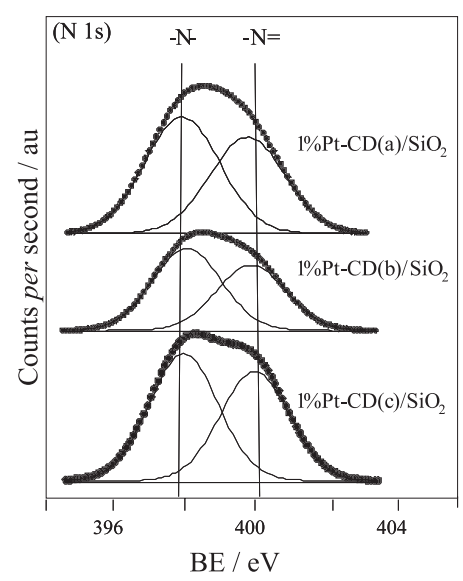

(b)

Figure 1. (a) Cinchona alkaloid with the two types of nitrogen atoms $\left(\mathrm{N}_{1}\right.$ and $\mathrm{N}_{1}$ ) detected by XPS. (b) XPS core level spectra of N1s for the studied catalysts.

Table 2 compiles the $\mathrm{Pt} / \mathrm{Si}$ and $\mathrm{N} / \mathrm{Si}$ atomic surface ratios. It can be seen that, as the $\mathrm{CD}$ concentration used in the synthesis increases, both the $\mathrm{Pt} / \mathrm{Si}$ and the N/Si atomic surface ratios also increase. This behaviour is explained by the stabilizing role played by the $\mathrm{CD}$ molecule during the synthesis. Thus, as the CD concentration increases, the formed metal crystallites do not have the possibility to grow, leading therefore to smaller metal particle sizes. Consequently, a higher amount of exposed $\mathrm{Pt}$ atoms should be expected. Additionally, once these aggregates were stabilized with $\mathrm{CD}$ molecules, which contain nitrogen atoms, the N/Si atomic surface ratio should also increase.

Table 2. Pt/Si and N/Si atomic surface ratios for the1wt.\% $\mathrm{Pt}-\mathrm{CD} / \mathrm{SiO}_{2}$ catalyst

\begin{tabular}{lccc}
\hline Catalyst & {$[\mathrm{CD}] \mathrm{mol} \mathrm{L}^{-1}$} & $\mathrm{Pt} / \mathrm{Si}$ & $\mathrm{N} / \mathrm{Si}$ \\
\hline (a) & 0.0022 & 0.0010 & 0.008 \\
(b) & 0.0074 & 0.0058 & 0.026 \\
(c) & 0.0098 & 0.0193 & 0.033 \\
\hline
\end{tabular}

\section{Catalytic activity}

\section{Hydrogenation of ethyl pyruvate}

Figure 2 shows a scheme of the hydrogenation of ethyl pyruvate (EP). It has been demonstrated that, using cinchonidine chiral alkaloid, it is possible to induce a preferential formation of $(R)$-lactate. ${ }^{43-44}$ In the present study the enantioselective hydrogenation of ethyl pyruvate was carried out in liquid phase at $298 \mathrm{~K}$ and 40 bar overall pressure on colloidal platinum and on $\mathrm{Pt}-\mathrm{CD} / \mathrm{SiO}_{2}$ catalysts obtained by impregnation of the colloids on the support. Experimental variables such as the weight of the catalysts

and the concentration of $\mathrm{CD}$ added with the substrate during the reaction were also studied. The hydrogenation of EP was carried out initially in the presence of $2 \mathrm{mg}$ of colloidal Pt. Activity results showed very low conversion level even after long reaction times. Thus, at $250 \mathrm{~min}$ the conversion values reached $11 \%$ for the catalyst with smaller particle size, and 9 and $7 \%$ for those with larger metal particles respectively. Regarding enantioselectivity, only a slight $e e$ for the $(R)$ ethyl lactate was found. The reaction performed with the catalyst with smaller particle size showed an ee value of $15 \%$, being even lower for the catalysts displaying higher particle sizes. It should be mentioned that the evolution of the conversion level with time for the three studied catalysts reached almost constant level after about $60 \mathrm{~min}$. Deactivation by sintering of the metal phase is responsible for the observed behaviour, which may occur under these mild experimental conditions in colloids but is not likely to occur with supported metal catalysts. Poisoning of the metal sites by traces of compounds present in the substrate solution has been also suggested as responsible for the deactivation. Nevertheless, in our experiments, the reactants were purified by distillation prior to the catalytic studies. Blank experiments performed in absence of catalysts did not show any conversion even after $400 \mathrm{~min}$.

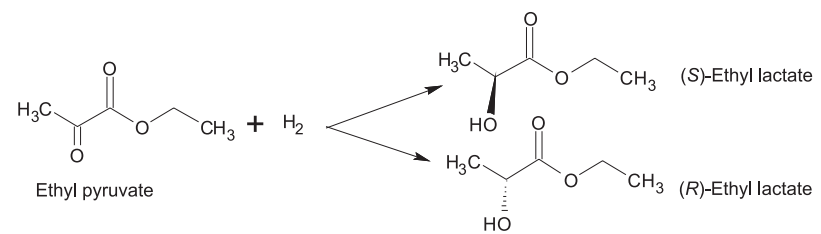

Figure 2. Hydrogenation of ethyl pyruvate.

Similar studies were carried out with the Pt-CD/SiO catalysts. Starting from the solids with the smallest metal particle size, the effect of the weight of catalysts was studied in the hydrogenation of EP $\left(0.02 \mathrm{~mol} \mathrm{~L}^{-1}\right)$ at $298 \mathrm{~K}$ and 40 bar of $\mathrm{H}_{2}$. The results showed a linear increase in the conversion level during the first $5 \mathrm{~min}$ of reaction and then the reaction rates decrease, reaching an almost complete conversion after two hours. There are significant differences in the conversion levels depending on the catalyst weight.

Under the same experimental conditions $\left(0.02 \mathrm{~mol} \mathrm{~L}^{-1}\right.$ solution of EP, $100 \mathrm{mg}$ of catalyst, $298 \mathrm{~K}$ and $40 \mathrm{bar}$ of $\mathrm{H}_{2}$ ), the three catalysts were tested. The time course of conversion is similar to that displayed by the colloids, although conversions are much higher than that exhibited by them. The trend was the same: the highest the CD concentration during the colloid synthesis, the highest the activity obtained. Thus, at the same reaction time, i.e. $250 \mathrm{~min}$, the conversion level increases from 80 to 99\% when decreasing the size of the Pt crystallites. With 
regard to the enantioselectivity, it is also affected by the characteristics of the metal clusters. Again, the ee depends on the metal particle size, being higher the ee for the $(R)$-ethyl lactate in the catalysts with lower particle size.

Table 1 shows the ee values for the catalysts prepared by the colloidal route in the presence of different chiral modifier concentrations. The catalytic behaviour of a non modified $\mathrm{Pt} / \mathrm{SiO}_{2}$ (prepared by impregnation of $\mathrm{H}_{2} \mathrm{PtCl}_{6}$ on silica followed by calcination and reduction) in the hydrogenation of EP leads to the racemic mixture, confirming that the chiral modifier is essential to induce chirality. It has been demonstrated in previous studies that metal particle size in Pt catalysts employed in asymmetric hydrogenation controls the enantioselectivity of the reaction. It has been found that, for a given $\mathrm{CD}$ concentration, metal particle sizes in the range of 3-4 $\mathrm{nm}$ show the maximum enantiomeric excess. This behaviour was explained on the basis of adsorption of $\mathrm{CD}$ on the active sites. Planar adsorption of the modifier on crystal faces is favoured when crystal dimensions are in the range of 3-4 nm, and this adsorption mode is the most appropriate to generate the open 3 conformers which are responsible for the formation of the $(R)$-enantiomer. On the other hand, planar adsorption of CD is limited on Pt particles smaller than $3 \mathrm{~nm} .{ }^{5}$

The results of the present work show the opposite trend. This particular behaviour can be due to the different approach chosen to prepare the catalysts. As they were prepared in the presence of $\mathrm{CD}$, it is likely that an important quantity of the modifier remained linked to the Pt surface atoms, being highest the amount of $\mathrm{CD}$ bonded to the smaller crystals. Therefore, the higher $e e$ values can be related to the higher $\mathrm{CD}$ concentration instead of particle size. It is well known that the concentration of added modifier during the catalytic reaction plays an important role in both activity and enantioselectivity in this kind of reactions. For this reason, the effect of addition of $C D$ with the substrate at the beginning of the reaction was also studied. Figure 3 shows the results obtained for the three catalysts. A typical bell type curve was found with each catalyst. The observed behaviour confirms that an optimum amount of $\mathrm{CD}$ is required to induce chirality. The ee displayed in the experiments without the addition of $\mathrm{CD}$, in the range of 23 to $34 \%$ for the different catalysts, is attributed to the $\mathrm{CD}$ linked to the metal during the synthesis. As can be seen in Figure 3, the amount of CD is not optimized to give a maximum $e e$, which depends on the metal particle size. At lower CD concentration, the Pt surface coverage is rather limited and consequently leads to lower values. As the $\mathrm{CD}$ concentration increases, also the enantioselectivity increases, up to reaching maximum $e e$. At higher $\mathrm{CD}$ concentration, flat adsorption of $\mathrm{CD}$ moieties on the metal surface is highly inhibited, being also possible

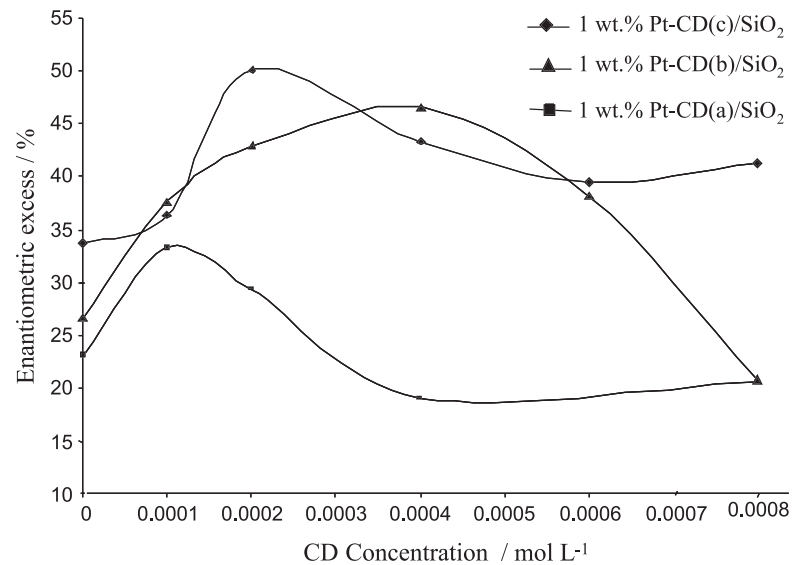

Figure 3. Effect of the CD concentration during the EP hydrogenation (298 K, 40 bar of $\mathrm{H}_{2}, 1 \mathrm{wt}$. \% Pt-CD/SiO 2 catalyst) on the ee of $(R)$-ethyl lactate.

the formation of $\mathrm{CD}$ dimers, $(\mathrm{CD})_{2} \cdot{ }^{45}$ Both facts made more difficult to induce the desired chirality.

Table 3 summarizes data on the pseudo first order reaction rates for EP hydrogenation determined in the presence of the studied catalysts at different CD concentrations added in situ. Experimental values up to 60 min were considered. It can be observed that an increase in $\mathrm{CD}$ values produces a decrease in the rate constants whatever the catalyst. Additionally, the values of the rate constants increase in parallel with the metal particle size. The exception is the catalyst with higher particle size, because at higher $\mathrm{CD}$ concentration the rate constant also decreases, but the enantioselectivity is favoured. Table 4 summarizes the conversion level, $e e$ values and the yield of $(R)$-ethyl lactate for the different catalysts under the experimental conditions employed in this work. Figure 4 displays the evolution of the concentrations of substrate and products during the reaction, for the catalysts with the highest metal particle size in the presence of $\mathrm{CD}$ added at the beginning of the reaction. It can be seen that the decrease in $\mathrm{CD}$ concentration follows a pseudo first order reaction kinetics and the products appear as a consequence of parallel reactions, being favoured the formation of $(R)$-ethyl lactate. Under the conditions tested, the reaction is complete after $150 \mathrm{~min}$.

\section{Hydrogenation of 1-Phenyl-1,2-propanedione on 1wt.\% $\mathrm{Pt}-\mathrm{CD} / \mathrm{SiO}_{2}$}

Figure 5 shows a scheme of the enantioselective hydrogenation of 1-phenyl-1,2-propanedione. The reaction was studied at $298 \mathrm{~K}$ and 40 bar of $\mathrm{H}_{2}$ using the catalyst $1 \mathrm{wt} . \% \mathrm{Pt}-\mathrm{CD}(\mathrm{c}) / \mathrm{SiO}_{2}$. It was found that, using this system, it is possible to induce the preferential formation of $(R)-1$ phenyl-1-hydroxy-2-propanone.

Under the conditions employed, the main products were the regioisomers $(R)$ - and (S)-1-hydroxy-1-phenylpropanone 
Table 3. Pseudo first order reaction rate constants for the hydrogenation of EP at $298 \mathrm{~K}$ and 40 bar of $\mathrm{H}_{2}$ on $1 \mathrm{wt} \% \mathrm{Pt}-\mathrm{CD} / \mathrm{SiO}_{2}$ at different CD concentrations

\begin{tabular}{|c|c|c|c|}
\hline \multirow[b]{2}{*}{$\mathrm{CD}\left(\mathrm{mol} \mathrm{L}^{-1}\right)$} & \multicolumn{3}{|c|}{$* \mathrm{k}\left(\min ^{-1}\right)$} \\
\hline & $\begin{array}{c}\text { 1wt. } \% \\
\text { Pt-CD(a)/SiO } 2\end{array}$ & $\begin{array}{c}1 \text { wt. } \% \\
\text { Pt-CD(b)/SiO } 2\end{array}$ & $\begin{array}{c}\text { 1wt.\%. } \\
\text { Pt-CD(c)/SiO }\end{array}$ \\
\hline 0 & 0.0035 & 0.0362 & 0.0269 \\
\hline $1.0 \mathrm{E}-04$ & 0.0105 & 0.0236 & 0.0209 \\
\hline $2.0 \mathrm{E}-04$ & 0.0074 & 0.0226 & 0.0111 \\
\hline $4.0 \mathrm{E}-04$ & 0.0050 & 0.0086 & 0.0095 \\
\hline $6.0 \mathrm{E}-04$ & 0.0149 & 0.0081 & 0.0067 \\
\hline 8.0E-04 & 0.0149 & 0.0065 & 0.0063 \\
\hline
\end{tabular}

*calculated up to $60 \mathrm{~min}$ of reaction.

Table 4. Conversion, enantiomeric excess and yield of $(R)$-ethyl lactate in the ethyl pyruvate hydrogenation at $250 \mathrm{~min}$

\begin{tabular}{lccc}
\hline Catalyst & $\begin{array}{c}\text { Conversion } \\
(\%)\end{array}$ & $\begin{array}{c}\text { ee } \\
(\%)\end{array}$ & $\begin{array}{c}\text { Yield of }(R) \text {-ethyl } \\
\text { lactate }(\%)\end{array}$ \\
\hline 1wt.\% Pt-CD(a)/SiO & 97 & $23^{1}$ & 60 \\
1wt.\% Pt-CD(b)/SiO 2 & 100 & $27^{1}$ & 63 \\
1wt.\% Pt-CD(c)/SiO & 100 & $34^{1}$ & 67 \\
1wt.\% Pt-CD(c)/SiO & 100 & $50^{2}$ & 76 \\
\hline
\end{tabular}

${ }^{1}$ Conditions: 40 bar, $298 \mathrm{~K}, 0.02 \mathrm{~mol} \mathrm{~L}^{-1}$ of EP in cyclohexane and $100 \mathrm{mg}$ of $1 \mathrm{wt} . \% \mathrm{Pt}-\mathrm{CD} / \mathrm{SiO}_{2} .{ }^{2}$ Under the same conditions in as in ${ }^{(1)}$ but with optimum concentration of CD: $2 \times 10^{-4} \mathrm{~mol} \mathrm{~L}^{-1}$ added in situ.

and $(R)$ - and (S)-2-hydroxy-1-phenylpropanone. No overhydrogenated products (diols F, G, H, I in Figure 5) were observed. In all catalytic tests the regioselectivity, defined as $r s=[B]+[C] /[D]+[E](B, C, D$ and $E$ in Figure 5), was lower than $5 \%$. This behaviour may be explained in terms of electronic effects, because the aromatic ring contributes to polarize the $\mathrm{C}=\mathrm{O}$ bond close to the ring to a higher extent, and therefore the reactions leading to $(R)$-1-phenyl-1-keto-2-propanol and (S)-1-phenyl-1-keto2 -propanol are less favoured. Figure 6 shows the evolution of substrate and products concentrations with time during the hydrogenation of 1-phenyl-1,2-propanedione on one representative catalyst, at $298 \mathrm{~K}, 40$ bar of $\mathrm{H}_{2}$ and $100 \mathrm{mg}$ of $1 \mathrm{wt} . \% \mathrm{Pt}-\mathrm{CD}(\mathrm{c}) / \mathrm{SiO}_{2}$. The results indicate that, under these experimental conditions, the catalyst is highly active with conversion close to $90 \%$ after $420 \mathrm{~min}$, but with lower $e e$ and $R / S$. Considering the previous results obtained in EP hydrogenation, it would be possible to enhance the yield of the desired products by adjusting CD coverage. For that reason, the effect of the $\mathrm{CD}$ concentration added at the beginning of the reaction was studied. The evolution of the conversion with time showed significant differences depending on the $\mathrm{CD}$ concentration. The curves follow

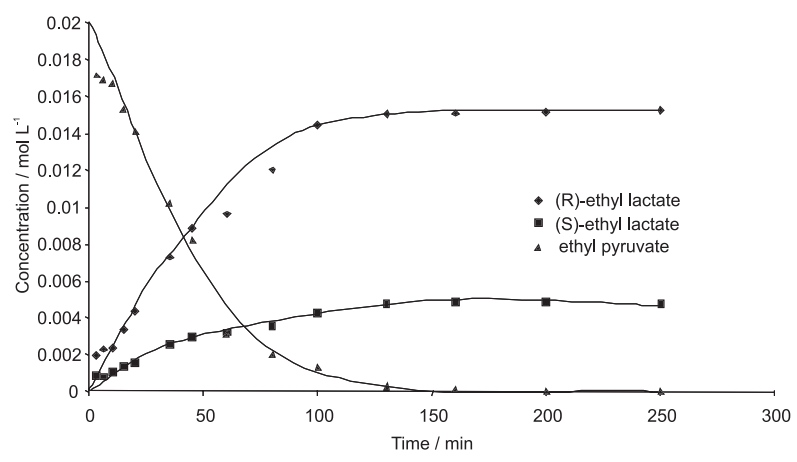

Figure 4. Evolution of substrate and products concentrations during the EP hydrogenation at $298 \mathrm{~K}$ and 40 bar of $\mathrm{H}_{2}$ on the 1 wt.\% Pt-CD(c)/ $\mathrm{SiO}_{2}$ catalyst.

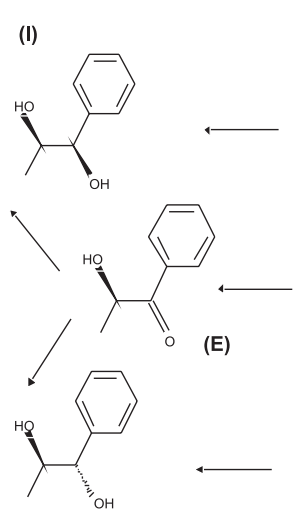

(H)

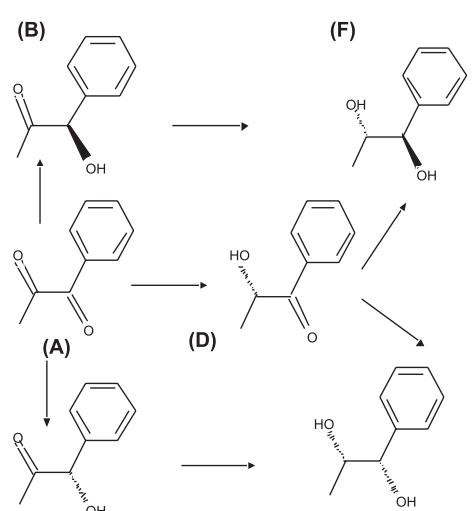

(C)

(G)
Figure 5. Reaction scheme of the hydrogenation of (A) 1-phenyl1,2-propanedione. (B) (R)-1-phenyl-1-hydroxy-2-propanone; (C) (S)-1-phenyl-1-hydroxy-2-propanone; (D) (S)-1-phenyl-1-keto-2propanol; (E) (R)-1-phenyl-1-keto-2-propanol; (F) $(1 R, 2 S)$-1-phenyl1,2-propanediol; (G) $(1 S, 2 S)$-1-phenyl-1,2-propanediol; (H) $(1 S, 2 R)-1$ phenyl-1,2-propanediol; (I) (1R,2R)-1-phenyl-1,2-propanediol.

the trends already shown and approach first order reaction kinetics. A summary of the first order reaction data obtained for the $1 \mathrm{wt} . \% \mathrm{Pt}-\mathrm{CD}(\mathrm{c}) / \mathrm{SiO}_{2}$ catalyst under the experimental conditions employed in this work is given in Table 5. An increase in the rate constant upon increasing CD concentration is observed. When the reaction is performed in absence of additional amount of $\mathrm{CD}$, the reaction takes place but at a lower reaction rate. The enantioselectivity also shows important changes with $\mathrm{CD}$ concentration. Therefore, the CD contributes to the generation of modified catalytic sites which are enantioselective and more active than the metal sites.

Figure 7 shows the effect of CD concentration on the enantiomeric excess of $(R)$-1-phenyl-1-hydroxy-2propanone. Trends similar to those previously reported can be observed: a bell-type plot with the maximum corresponding to an ee value of $42 \%$ was found. This behaviour can be explained on the basis of surface coverage as discussed previously. The fact that $e e$ values 
Table 5. Pseudo first order reaction rate constants as a function of CD concentration for the 1-phenyl-1,2-propanedione hydrogenation on 1wt.\% $\mathrm{Pt}-\mathrm{CD}(\mathrm{c}) / \mathrm{SiO}_{2}$ catalyst

\begin{tabular}{cc}
\hline $\mathrm{CD}\left(\mathrm{mol} \mathrm{L}^{-1}\right)$ & Reaction rate constant $\left(\mathrm{min}^{-1}\right)$ \\
\hline 0 & 0.0008 \\
$1.0 \mathrm{E}-04$ & 0.0014 \\
$2.0 \mathrm{E}-04$ & 0.0016 \\
$4.0 \mathrm{E}-04$ & 0.0020 \\
$6.0 \mathrm{E}-04$ & 0.0026 \\
$8.0 \mathrm{E}-04$ & 0.0028 \\
\hline
\end{tabular}

Conditions: $\mathrm{T}=298 \mathrm{~K}, \mathrm{P}_{\mathrm{H}_{2}}=40 \mathrm{bar}, 100 \mathrm{mg}$ of $1 \mathrm{wt} . \% \mathrm{Pt}-\mathrm{CD}(\mathrm{c}) / \mathrm{SiO}_{2}$, solvent $=$ cyclohexane.

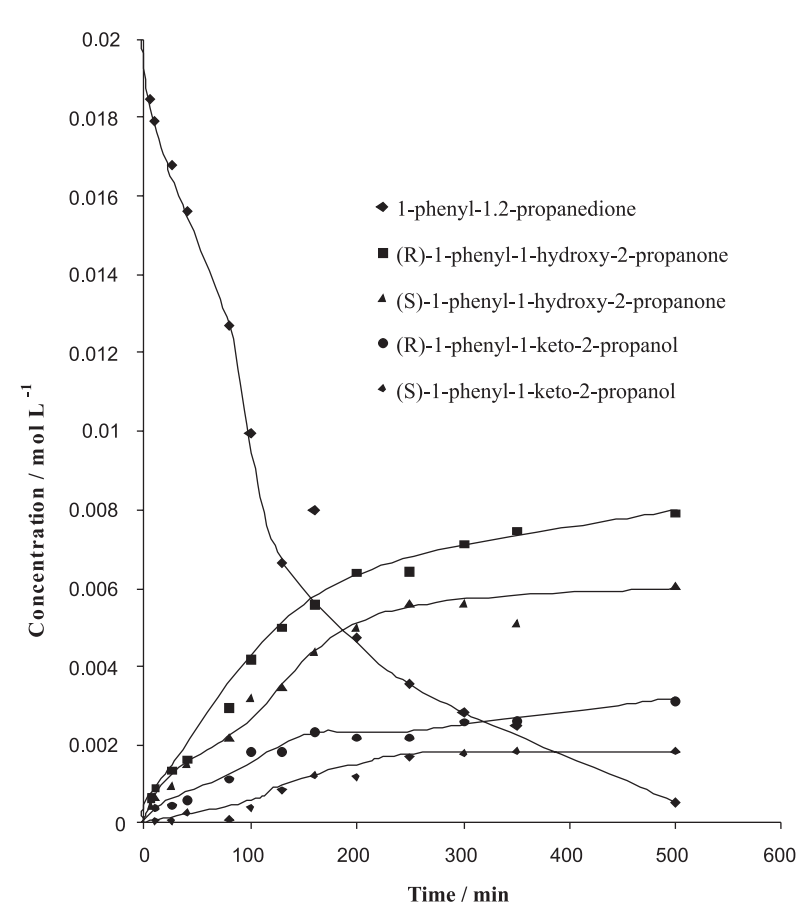

Figure 6. Evolution of reactant and products concentrations during the hydrogenation of 1-phenyl-1,2-propanedione at $298 \mathrm{~K}$ and 40 bar of $\mathrm{H}_{2}$, with $100 \mathrm{mg}$ of $1 \mathrm{wt} . \% \mathrm{Pt}-\mathrm{CD}(\mathrm{c}) / \mathrm{SiO}_{2}$ catalyst.

are much lower than those observed for the same catalyst in the ethyl pyruvate hydrogenation (under similar reaction conditions) can be understood by comparing the nature of the substrate. The adsorption properties of both molecules on the metal centers are different; the adsorption of the dione is stronger as a consequence of the aromatic ring. Therefore, the adsorption of the 1-phenyl1,2-propanedione on the non-modified sites is stronger than that for EP and consequently the enantioselectivity is lower. Even though the obtained ee values are rather low, confirming the difficulties to induce chirality in this reaction, they are not too far from the best reported values for enantioselectivity in the same system. ${ }^{19-26}$

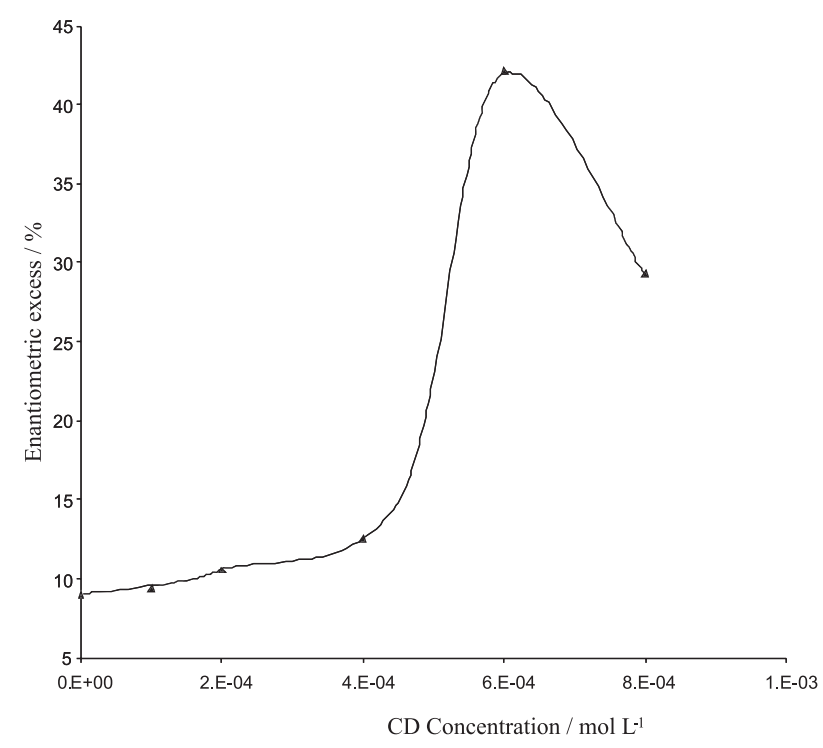

Figure 7. Effect of CD concentration on the enantiomeric excess of (R)-1-phenyl-1-hydroxy-2-propanone during the hydrogenation of 1-phenyl-1,2-propanedione on 1wt.\% Pt-CD(c)/SiO 2 at $298 \mathrm{~K}$ and $40 \mathrm{bar}$ of $\mathrm{H}_{2}$.

\section{Conclusions}

The results presented here show that it is possible to prepare chiral metal supported catalysts when the metallic component is formed from a metal dispersion in the presence of the chiral modifier as stabilizer. The amount of modifier strongly affects both the particle size and the catalytic behaviour. Higher activity and better enantioselectivity were observed for the catalyst with smaller metal particle size in the EP hydrogenation. The addition of $\mathrm{CD}$ during the catalytic reaction contributes to improve the behaviour. The optimum amount of $\mathrm{CD}$ required depends on the nature of the catalysts and the ee exhibits a bell-type dependence on CD concentration. Similar trends were obtained in the hydrogenation of the dione, although a lower enantiomeric excess was obtained. This behaviour was explained in terms of the differences in the adsorption of both substrates on the metal sites.

\section{Acknowledgements}

The authors thank the FONDECYT Grant 1061001 for financial support and D. Ruiz thanks MECESUP for a graduate fellowship.

\section{References}

1. Rylander, P.; Catalytic Hydrogenation over Platinum Metals; Academic Press: New York, 1967.

2. Cerveny, L.; Ruzicka, V.; Catal. Rev. Sci. Eng. 1982, 24, 503. 
3. Farnetti, E.; Pesce, M.; Kaspar, J.; Spogliarich, R.; Graziani, M.; J. Chem. Soc. 1986, 1, 746.

4. Allmag, G.; Grass, F.; Grosselin, J. M.; Mercier, C.; J. Mol. Catal. A: Chem. 1991, 66, 227.

5. Wells, P. B.; Wilkinson, A. G; Top. Catal. 1998, 5, 39.

6. Baiker, A.; J. Mol. Catal. A: Chem. 1997, 115, 473.

7. Studer, M.; Blaser, H. U.; Exner, C.; Adv. Synth. Catal. 2003, $45,345$.

8. Baiker, A.; Blaser, H. U.; In Handbook of Heterogeneous Catalysis; Ertl, G.; Knözinger, H.; Weitkamp, J., eds; WileyVCH: Wheinhem, Germany, 1997, v.5, 2422.

9. Baiker, A.; Curr. Opin. Solid State Mater. Sci. 1998, 3, 86.

10. a) Huck, W. R.; Mallat, T.; Baiker, A.; J. Catal. 2000, 193, 1; b) Huck, R.; Mallat, T.; Baiker, A.; Catal. Lett. 2002, 80, 87.

11. Exner, C.; Pfaltz, A.; Studer, M.; Blaser, H. U.; Adv. Synth. Catal. 2003, 345, 1253.

12. Murzin, D. Y.; Mäki-Arvela, P.; Toukoniitty, E.; Salmi, T.; Catal. Rev. Sci. Eng. 2005, 47, 175.

13. Baiker, A.; Catal. Today 2005, 100, 159.

14. Mallat, T.; Orglmeister E.; Baiker A.; Chem. Rev. 2007, 107, 4863.

15. Parada, J.; Herrera, J.; Pedraza, A.; J. Braz. Chem. Soc. 2009, $20,74$.

16. Orito, Y.; Imai, S.; Niwa S.; Nguyen, G. H.; J. Synth. Org. Chem. Jpn. 1979, 37, 173.

17. Orito, Y.; Imai, S.; Niwa, S.; J. Chem. Soc. Jpn. 1979, 1118.

18. Orito, Y.; Imai, S.; Niwa, S.; J. Chem . Soc. Jpn. 1980, 670.

19. Toukoniitty, E.; Mäki-Arvela, P.; Kuzma, M.; Villela, A.; Neyestanaki, A. K.; Salmi, T.; Sjöholm, R.; Leino, R.; Laine, E.; Murzin, D. Y.; J. Catal. 2001, 204, 281.

20. Toukoniitty, E.; Mäki-Arvela, P.; Wärna, J.; Salmi, T.; Catal. Today 2001, 66, 411.

21. Toukoniitty, E.; Mäki-Arvela, P.; Villela, A. N.; Neyesatnnaki, A. K.; Salmi, T.; Leino, R.; Sjöholm, R.; Laine, E.; Väyrynen, J.; Kooyman, P.; Catal. Today 2000, 60, 175.

22. Toukoniitty, E.; Mäki-Arvela, P.; Neyestanaki, A. K; Laine, E.; Mikkola, J. P; Salmi, T.; Murzin, D. Y.; React. Kinet. Catal. Lett. 2001, 3, 73.

23. Toukoniitty, E.; Mäki-Arvela, P; Sjöholm, R.; Laine, E.; Salmi, T.; Murzin, D. Y.; React. Kinet. Catal. Lett. 2002, 75, 21.

24. Marzialetti, T.;. G-Fierro, J. L.; Reyes P.; Catal. Today 2005, 107,235

25. Marzialetti, T.; Oportus, M.; Ruiz, D.; G-Fierro, J. L; Reyes, P.; Catal. Today 2008, 133, 711.
26. Busygin I.; Wärna J.; Toukoniitty E.; Murzin D.; Leino R.; J. Catal. 2008, 254, 339.

27. Gala, D.; DiBenedetto, D. J.; Clark, J. E; Murphy, B. L.; Schumacher, D. P.; Steinman, M.; Tetrahedron Lett. 1996, 35 , 611.

28. Subramanian, P. M.; Chatterjee, S. K.; Bhatia, M. C.; J. Chem. Technol. Biotechnol. 1987, 39, 215.

29. Blaser, H. U.; Studer, M.; Acc. Chem. Res. 2007, 40, 1348.

30. Roucoux, A.; Schulz, J.; Patin, H.; Chem. Rev. 2002, 102, 3757.

31. Bönnemann, H.; Brijoux, W.; Nanostruct. Mater. 1995, 5, 135.

32. Bönnemann, H.; Brijoux, W.; In Active Metals: Preparation, Characterization and Applications; Furstner, A. ed.; VCH: Weinheim, New York 1996, 339.

33. Bönnemann, H.; Brijoux, W.; Brinkmann, R.; Fretzen, R.; Joussen, T.; Köppler, R.; Korall, B.; Neiteler, P.; J. Mol. Catal. A: Chem. 1994, 86, 129.

34. Bönnemann, H.; Braun, G.; Brijoux, W.; Brinkmann, R.; Schulze, A.; Seevogel, K.; Siepen, K.; J. Organomet. Chem. 1996, 520, 143.

35. Bönnemann, H.; Braun, G. A.; Angew. Chem., Int. Ed. Engl. 1992, 35, 1996.

36. Bönnemann, H.; Braun, G. A.; Chem. Eur. J. 1997, 3, 1200.

37. Ruiz, D.; Reyes, P.; J. Chil. Chem. Soc. 2008, 53, 1740.

38. Bürgi, T.; Baiker, A.; J. Am. Chem. Soc. 1998, 120, 12920.

39. Durán, L.; Rothenberg, G.; Appl. Organomet. Chem. 2008, 22 , 288.

40. Gaikwad, A. V.;Holuigue, A.; Thathagar M. T.; Elshof, J.; Rothenberg, G.; Chem. Eur. J. 2007, 13, 6908.

41. Thathagar M. T.; Kooyman, P. J.; Boerleider, R.; Jansen, E.; Elsevier, C. J.; Rothenberg, G.; Adv. Synth. Catal. 2005, 347, 1965.

42. Arends, I. W.; Sheldon, R. A.; Appl. Catal., A 2001, 212, 175.

43. Margitfalvi, J. L.; Tálas, E.; Appl. Catal., A 2006, 301, 187.

44. Simons, K. E.; Meheux, P. A.; Griffiths, S. P.; Sutherland, I. M.; Johnston, P.; Wells, P. B.; Carley, A. F.; Rajumon, M. K.; Roberts M. W.; Ibbotson, A.; Rec. Trav. Chim. Pays-Bas, 1994, 113,365 .

45. Margitfalvi, J. L.; Talas, E.; Hegedus, M.; Chem. Commun. 1999, 1,645 .
Received: February 3, 2009

Web Release Date: November 19, 2009 